\title{
Transition from conventional to low-input agriculture changes soil fertility and biology
}

\author{
Kate M. Scow $\square$ Oscar Somasco a Nirmala Gunapala $\square$ Sean Lau $\square$ Robert Venette \\ Howard Ferris $\square$ Robert Miller $\square$ Carol Shennan
}

\begin{abstract}
Growers converting from conventional to low-input and organic farming systems must rely on or-
\end{abstract} ganic sources for adequate soil fertility. At the Sustainable Agriculture Farming Systems (SAFS) project at UC Davis, we measured soil fertility and biological parameters in four farming systems. By the end of the first 4 years, $\mathrm{pH}$ and percent nitrogen were consistently higher in organic and lowinput than conventional plots for all crops. Levels of organic matter, phosphorus and potassium were significantly higher in the organic than conventional 2-year plots. Microbial biomass levels were consistently higher in organic and low-input systems, while plant parasitic nematode numbers were consistently lower. Nitrogen deficiency appeared to be a problem in organic tomatoes during the transition period. More research is needed into the dynamics of soil nutrient availability in low-input systems. For instance, we may need to develop new methods of assessing soil fertility in organically fertilized systems.

Soil fertility is an important determinant of the economic survival of a farming system. Management systems that rely on organic inputs as sources of fertilizer have different dynamics of soil nutrient availability than systems receiving mineral sources. These $d y-$ namics are not yet well understood, especially in the irrigated systems of the Mediterranean climate of California's Central Valley.
Though biological processes control the availability of many soil nutrients, interest in the soil biological community has been overlooked because high levels of mineral fertilizer may overshadow or inhibit biological activities. Heavy applications of pesticides also may alter the soil community and decrease rates of certain key processes, for example, nitrification. Understanding soil biology is especially important in cover crop systems, which rely on below-ground biota to liberate plant nutrients. Cover crops provide organic forms of carbon and nitrogen that are quickly metabolized to inorganic nitrogen and other nutrients, primarily by bacteria and fungi. Nitrogen is also mineralized as predators of bacteria and fungi, such as protozoa and microbivorous ("microorganismeating") nematodes, graze on prey that contain more nitrogen than required by the predators. Although more research attention is given to plant parasitic nematodes, bacterivores (bacterial feeders) and fungivores (fungal feeders) make up a large portion of the nematode community (fig. 1). Excess nitrogen generated by grazing is released to the soil and becomes available for plant uptake (conceptualized in fig. 2). Understanding the relationships among members of the soil community and the factors controlling the timing and release of nutrients by biological processes will be important for the optimal management of cropping systems.

At the Sustainable Agriculture Farming Systems (SAFS) project at UC

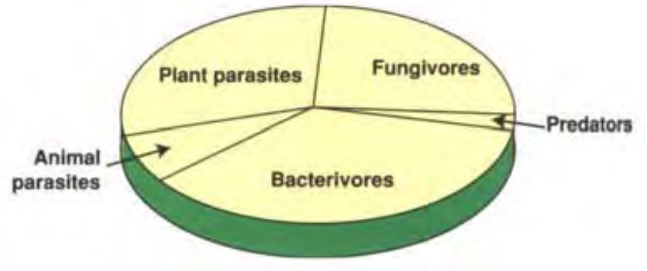

Flg. 1. Relative proportions of different trophic groups of nematodes making up the total nematode community.

Davis, we studied four farming systems during the first 4-year rotation following conversion from conventional management practices. The rotation system consisted of processing tomatoes, safflower, field corn and a cereal/bean double crop. The four farming systems included two conventional (2-year and 4-year rotation) systems, a low-input system and an organic system.

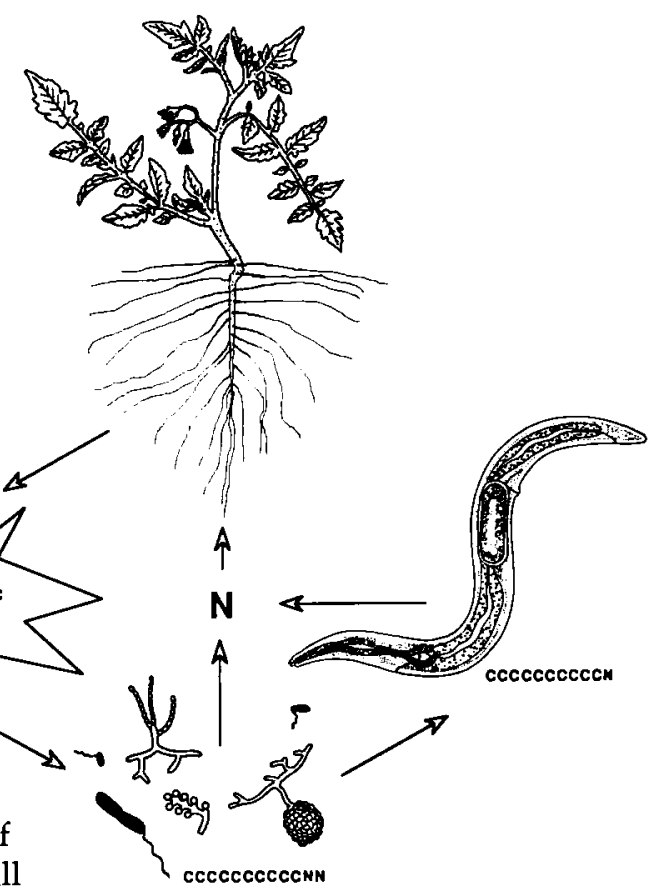

Fig. 2. Conceptual diagram of nitrogen flow $\mathrm{h}$ soil. Figures not to scale. C refers to carbon; $\mathbf{N}$ refers to nitrogen. Carbon-to-nitrogen ratios were estimated from literature values. 
During the transition from a conventional to a low-input or organic management system, there are many changes in the chemical and biological properties of soil. The changes result in part from significantly higher inputs of carbon associated with organic forms of fertilizer and the reduction or termination of pesticide use. Studies from other regions of the United States indicate that it takes several years of organic management for previously conventional soils to begin to function successfully in terms of nutrient cycling. Protocols of the California Certified Organic Farmers (CCOF) association require a 3-year transition period of organic management before a farm can be certified as organic. Although the requirement is driven primarily by the need to eliminate pesticide residues, the 3-year period may also allow time for the soil microbial community to adapt to the higher rates of nutrient cycling required in an organic system. Limited crop growth due to nitrogen deficiency is a commonly recognized problem during the transition period, but less is known about other nutrient limitations.

The objectives of this study were to determine if soil nutrient and biological parameters change during the transition from conventional to low-input or organic farming systems. The study was conducted in the experimental plots of the Sustainable Agriculture Farming Systems (SAFS) project at UC Davis. During the first rotation, from 1988 to 1992 , we measured carbon and nitrogen inputs, soil fertility, microbial biomass and nematode numbers and diversity in the different farming systems, with an emphasis on tomatoes.

Our study is one component of a larger project and is accompanied in this issue by reports describing the overall project, farming systems and agronomic aspects (see pp. 14-19); pests and weeds (see pp. 27-33) and economics (see pp. 34-42).

\section{Methods}

The SAFS project is located at the Agronomy Field Station at UC Davis. Details on inputs for each system by year are shown in table 1. Detail on the rotations and practices associated with

\begin{tabular}{|c|c|c|c|}
\hline & & Organic and low inputt & Conventional 2- and 4-year \\
\hline \multirow[t]{4}{*}{ Tomato } & 1989 & Chicken manure 3\% N @ 2.4 ton & $\begin{array}{l}\text { Preplant 0-45-0 @ } 200 \mathrm{lb} \\
\text { Starter 6-20-20@120 lb } \\
\text { Sidedress 46-0-0 @ } 304 \mathrm{lb}\end{array}$ \\
\hline & 1990 & $\begin{array}{l}\text { Plant vetch (Lana) @ } 66 \mathrm{lb} \\
\text { O only: Replant vetch (Lana) @ } 20 \text { lb \& } \\
\text { Purple @ } 40 \mathrm{lb} \\
\text { Preplant 0-28-0 @ } 89 \mathrm{lb}\end{array}$ & $\begin{array}{l}\text { Preplant 6-20-20 @ } 120 \mathrm{lb} \\
\text { Sidedress 46-0-0 @150 lb }\end{array}$ \\
\hline & 1991 & $\begin{array}{l}\text { Plant vetch (Lana) @ } 55 \mathrm{lb} \\
\text { Lu only: Sidedress } 34-0-0 \text { @150 lb }\end{array}$ & $\begin{array}{l}\text { Starter 6-20-20@100 lb } \\
\text { Sidedress 46-0-0 @ 260 lb }\end{array}$ \\
\hline & 1992 & $\begin{array}{l}\text { Plant vetch (Lana) @ } 50 \mathrm{lb} \\
\text { O only: Chicken Manure } 3 \% \mathrm{~N} @ 1.5 \mathrm{ton} / \mathrm{ac} \\
\text { Starter (transplants) 8-24-6 @ } 10 \text { gal } \\
\text { LI only: Sidedress 34-0-0 @ } 88 \mathrm{lb} \\
\text { O only: Topdress fishpowder 12-.25-1 @ } 5 \mathrm{lb} \\
\text { \& kelp 3-.25-.15 @ } 1 \text { gal }\end{array}$ & $\begin{array}{l}\text { Starter 6-20-20, C2 @ } 160 \mathrm{lb} \\
\quad \text { \& C4 @100 lb } \neq \\
\text { Sidedress 34-0-0 @ } 350 \mathrm{lb}\end{array}$ \\
\hline \multirow[t]{4}{*}{ Safflower } & 1989 & Dairy manure 2.5\%@ 3 ton & $\begin{array}{l}\text { Preplant 21-0-0 @ } 200 \mathrm{lb} \& \text { 0- } \\
45-0 @ 475 \mathrm{lb}\end{array}$ \\
\hline & 1990 & Plant vetch (Lana) @80 lb & Preplant 46-0-0 @ $330 \mathrm{lb}$ \\
\hline & 1991 & Plant vetch (Lana) @ 55 lb & Sidedress $46-0-0 @ 326$ lb \\
\hline & $1992 \S$ & $\begin{array}{l}\text { Chicken manure } 3 \% \text { @ } 4 \text { ton } \\
\text { LI only: Sidedress } 46-0-0 @ 173 \text { lb }\end{array}$ & Sidedress 46-0-0 @ $173 \mathrm{lb}$ \\
\hline \multirow[t]{4}{*}{ Corn } & 1989 & $\begin{array}{l}\text { LI only: Preplant 0-45-0 @ } 200 \mathrm{lb} \\
\text { Chicken manure } 3.4 \% \mathrm{~N} @ 3.2 \text { ton }\end{array}$ & $\begin{array}{l}\text { Preplant 0-45-0 @ } 200 \mathrm{lb} \\
\text { Starter 6-20-20 @ } 250 \mathrm{lb} \\
\text { Sidedress 46-0-0 @ 435 lb }\end{array}$ \\
\hline & 1990 & $\begin{array}{l}\text { Plant vetch (Lana) @ } 90 \text { lb } \\
\text { Starter 0-28-0 @ } 178 \text { lb }\end{array}$ & $\begin{array}{l}\text { Starter 6-20-20 @ } 250 \mathrm{lb} \\
\text { Sidedress 46-0-0 @ } 430 \mathrm{lb}\end{array}$ \\
\hline & 1991 & $\begin{array}{l}\text { Plant vetch (Lana) @ } 55 \text { lb } \\
\text { Sheep Manure 4\% @ } 2 \text { ton }\end{array}$ & $\begin{array}{l}\text { Starter 6-20-20@ } 200 \mathrm{lb} \\
\text { Sidedress 46-0-0 @ } 391 \mathrm{lb}\end{array}$ \\
\hline & 1992 & $\begin{array}{l}\text { Plant vetch (Lana) @ } 50 \mathrm{lb} \\
\text { O only: Chicken manure } 3 \% \text { @ } 2 \text { ton } \\
\text { LI only: Starter 6-20-20 @ } 100 \mathrm{lb} \\
\text { LI only: Sidedress } 34-0-0 \text { @ } 205 \mathrm{lb}\end{array}$ & $\begin{array}{l}\text { Starter 6-20-20@100 lb } \\
\text { Sidedress 46-0-0 @ } 390 \mathrm{lb}\end{array}$ \\
\hline \multirow[t]{4}{*}{ wheat } & 1989 & LI only: Preplant 0-45-0 @ 200 lb & $\begin{array}{l}\text { Preplant 0-45-0@200 lb } \\
\text { Starter 21-0-0@ } 570 \mathrm{lb}\end{array}$ \\
\hline & 1990 & No external inputs. & $\begin{array}{l}\text { Preplant 21-0-0 @ } 100 \mathrm{lb} \& 11 \\
52-0 @ 140 \mathrm{lb} \\
\text { Topdress } 34-0-0 @ 160 \mathrm{lb}\end{array}$ \\
\hline & 1991 & No external inputs. & $\begin{array}{l}\text { Preplant } 11-52-0 @ 100 \mathrm{lb} \& 46-0-0, \\
\text { C2 @ } 87 \mathrm{lb} \& \mathrm{C} 4 \text { @ @ } 174 \mathrm{lb \neq} \\
\text { Topdress } 34-0-0, \mathrm{C} 2 @ 150 \mathrm{lb} \& \\
\text { C4 @ } 225 \mathrm{lbf}\end{array}$ \\
\hline & 1992 & No external inputs. & $\begin{array}{l}\text { Preplant 46-0-0, C2 @ } 260 \mathrm{lb} \& \\
\text { C4 @ 350 lb } \\
\text { Starter 6-20-0 @ } 100 \mathrm{lb} \\
\text { Topdress 34-0-0 @ } 160 \mathrm{lb}\end{array}$ \\
\hline Beans I & 1992 & No external inputs. & $\begin{array}{l}\text { Sidedress 21-0-0-24 @ } 381 \text { lb } \\
\text { (Conventional 4-year only) }\end{array}$ \\
\hline \multicolumn{4}{|c|}{$\begin{array}{l}\text {-All inputs are in units of material per acre. } \\
\text { tInputs are for both systems unless otherwise indicated. } \\
\text { †C2=applied to conventional } 2 \text {-year only; C4=applied to conventional 4-year only. } \\
\text { SReplanted to beans. } \\
\text { †No fertilizers applied in } 1989,1990,1991 .\end{array}$} \\
\hline
\end{tabular}




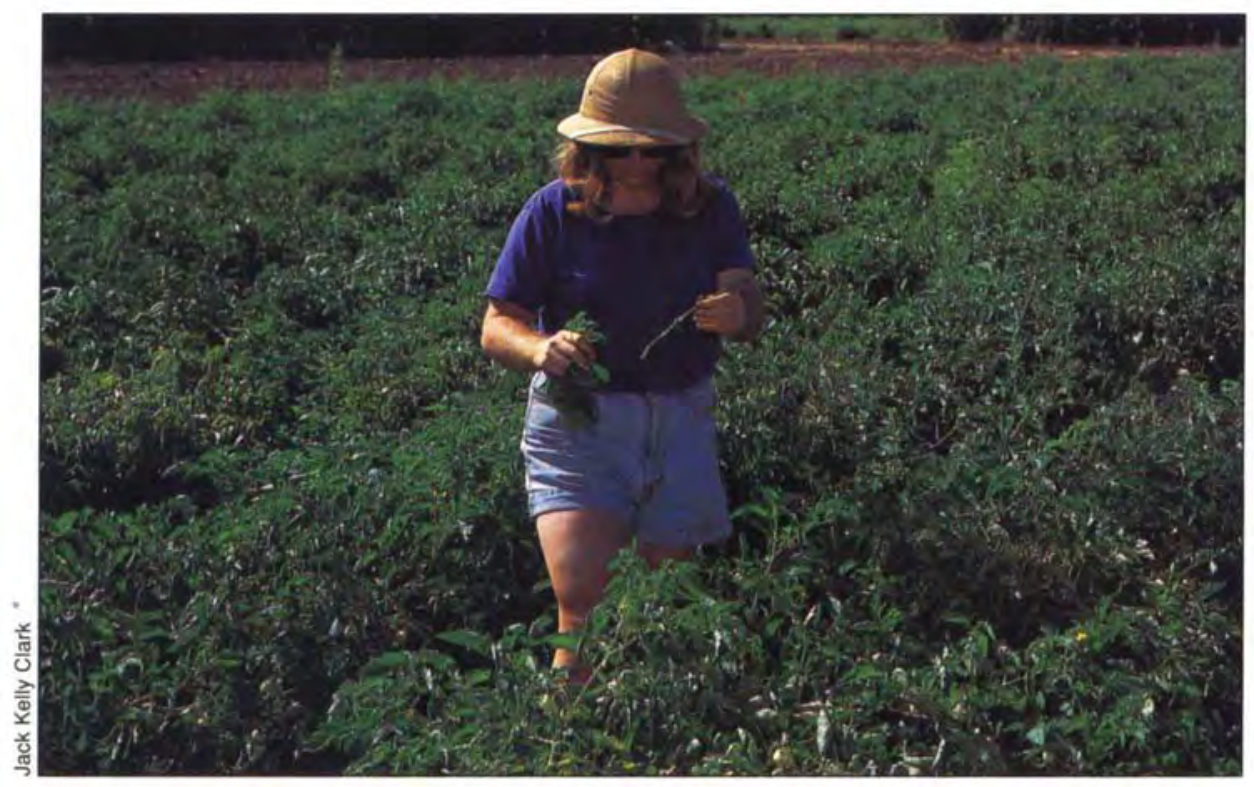

each farming system are given by Temple et al. (pp. 14-19). All soil samples were collected by pooling 20 to 30 cores of 2.5-centimeter diameter from each plot in all blocks of the study site. Soil for chemical analyses was collected at 0 - to 30 -centimeter depth in all plots in 1988 before the experiment started and again in 1992. Measurements included $\mathrm{SO}_{4}-\mathrm{S}$, total nitrogen, bicarbonate extractable phosphorus, ammonium acetate extractable potassium, saturated paste $\mathrm{pH}$ and percent organic carbon. Soil samples collected at a 0 - to 15-centimeter or 0to 30-centimeter depths were analyzed for nitrate and ammonium at different times over the growing season in 1990 to 1992. Crop tissue samples were collected from 20 plants per plot. Tomato petioles were sampled at the fourth leaf from the growing tip, during the plant growth stages of early bloom, 1-inch fruit diameter and fruit at first color. For corn, flag leaves at silking and basal corn stalks at physiological maturity were sampled and analyzed for $\mathrm{NO}_{3}-\mathrm{N}$. All soil and plant nutrient analyses were performed by the Division of Agriculture and Natural Resources Analytical Laboratory, UC Davis.

Microbial biomass carbon was determined in tomato plots by the chloroform fumigation-extraction method in soil samples collected from the top 15-centimeter depth. Soil samples for the annual inventory of nematodes were taken to a depth of 30 centimeters in all plots. Nematodes were extracted from a $300-$ to $400-\mathrm{cm}^{3}$ subsample of soil by elutriation and sugar centrifugation. For each sample, the total number of nematodes was counted and a subset of 200 to 300 individuals identified to genus and, where possible, species.

\section{Soil biology shifts}

Inputs and soil fertility. Baseline soil data collected in 1988 prior to establishment of the experiment showed no significant differences among plots. Table 2 summarizes baseline data for
Agronomist Diana Friedman takes tomato petiole samples. Plant tissue and soil samples were taken to assess the amount of nitrogen contributed by cover crops.

all crops and all farming systems. During the subsequent 4 years, soils in the different systems have received inorganic fertilizer (conventional 2-year, conventional 4-year and low-input), crop residues (all systems), cover crops (organic and low-input) and manure or compost (organic) (table 3 ). Dry matter, and hence carbon, inputs were highest in the organic and lowinput systems. Fertilizer inputs in both conventional farming systems more than compensated for nitrogen removal in harvested material, assuming zero loss by denitrification and leaching. The estimates of nitrogen input to the organic and low-input systems assumed that the leguminous cover crop obtained $50 \%$ of its nitrogen from fixation of atmospheric nitrogen and the remaining $50 \%$ from soil. Based on this assumption, external nitrogen inputs in the organic system barely compensated for nitrogen removal, and in the low-input system removal exceeded external inputs over the 4 years. Thus, the assumption that $50 \%$ of the cover crop nitrogen came from nitrogen fixation may have been an underestimate and warrants further investigation.

By 1992, various soil chemical properties reflected differences in inputs, and these values are shown in table 4 for all crops combined. Values for $\mathrm{pH}$ and percent nitrogen were consistently higher in the organic and low-input than conventional plots. Levels of manganese were lower, whereas organic carbon, phosphorus and potassium were significantly higher in the

\begin{tabular}{lc}
\multicolumn{2}{l}{ TABLE 2. Baseline soll data in all plots in $\mathbf{1 9 8 8}$} \\
\hline \hline Parameter & \multicolumn{1}{c}{ Value } \\
\hline $\mathrm{pH}$ & 6.9 \\
Electrical conductivity (EC) & $0.77 \mathrm{mmhos} / \mathrm{cm}$ \\
Organic carbon & $0.79 \%$ \\
Phosphorus (P) & $12.1 \mathrm{ppm}$ \\
Potassium (K) & $277 \mathrm{ppm}$ \\
Calcium $(\mathrm{Ca})$ & $1.8 \mathrm{meq} / \mathrm{L}$ \\
Magnesium $(\mathrm{Mg})$ & $3.5 \mathrm{meq} / \mathrm{L}$
\end{tabular}

TABLE 3. Dry matter and nitrogen inputs into soil in tomato plots by farming system, 1989-1992

\begin{tabular}{|c|c|c|c|c|c|}
\hline \multirow[b]{3}{*}{ System } & \multirow{3}{*}{$\begin{array}{l}\text { Dry matter } \\
\text { total input }\end{array}$} & \multicolumn{4}{|c|}{ Nitrogen } \\
\hline & & \multicolumn{2}{|c|}{ External inputs } & \multirow{2}{*}{$\begin{array}{l}\text { Cycled } \\
\text { plant N† }\end{array}$} & \multirow{2}{*}{$\begin{array}{l}\text { Removed } \\
\text { at harvest }\end{array}$} \\
\hline & & Inorganic & Organic* & & \\
\hline & tons/acre & & & & \\
\hline Conventional 4-year & 17.8 & 612 & 0 & 382 & 506 \\
\hline Conventional 2-year & 14.6 & 488 & 0 & 270 & 440 \\
\hline Low-input & 21.4 & 61 & 333 & 417 & 494 \\
\hline Organic & 24.2 & 0 & 407 & 461 & 384 \\
\hline
\end{tabular}

"External organic inputs for low-input and organic calculated as organic amendments $+0.5 ¥$ cover-crop nitrogen (i.e., portion derived by nitrogen fixation).

tSoil-derived nitrogen returned to soil in form of plant residues. Calculated for low-input and organic systems as crop residue $+0.5 ¥$ cover-crop nitrogen. 
organic than conventional 2-year plots. Although statistically significant, some of these differences may not be important agronomically. There were no significant differences in cation exchange capacity, sulfate, electrical conductivity, calcium, magnesium and zinc. The fact that soils in the low-input plots showed an increase in percent nitrogen relative to conventional plots suggests, as discussed above, that there was greater nitrogen fixation by the cover crops than estimated in the nitrogen budget presented in table 3 . The low-input and organic systems derive $85 \%$ of their nitrogen from cover crops, rather than approximately $50 \%$, as estimated, illustrating that the nitrogen budget is particularly sensitive to assumptions about nitrogen contributions from cover crops.

Nitrogen availability, perhaps combined with early season weed pressure (see pp. 14-19 and 27-33), may be an important factor in determining tomato yields during the transition to organic production. Prior to 1992, tomato plants in the organic system typically appeared stunted and yellow early in the season, did not compete well with weeds (see pp. 27-33) and had yields lower than tomatoes grown in the conventional system (table 5). Soil nitrate levels in the organic tomatoes in 1990 and 1991, however, were higher than or equivalent to levels in the conventional system on the dates measured (table 6). In 1992, when organic and conventional yields were comparable, nitrate levels in organic plots were also higher than or equivalent to levels in the conventional plots.

Tomato petiole nitrate analysis indicated that nitrogen was deficient in all systems in 1991, whereas it was deficient in only the organic system in 1990 and 1992. Since yields were comparatively high in the conventional 4year system in 1991, it is unlikely that plants were truly nitrogen-deficient and suggests either that the petiole test is unreliable or that samples were actually taken later than early bloom that year. Furthermore, organic plants had the lowest petiole nitrate in all years, even in 1992, when yields were comparable among all systems (table 5). To test critically the reliability of peti- ole nitrate as an indicator of nitrogen sufficiency in tomatoes, we are currently growing plants in both organic and conventionally managed soils that have received different levels of nitrogen inputs.
For corn, the percent nitrogen at silking agreed reasonably well with yields in 1990 and 1991 (table 5).

Lower yields in organic and low-input systems in 1991 were probably due to the decision to use a reduced tillage

\section{TABLE 4. Differences in soil properties among farming systems across all crops in 1992}

\begin{tabular}{lcccc}
\hline \hline & & & \multicolumn{2}{c}{ Conventional } \\
\cline { 4 - 5 } Parameter & Organic & Low-input & 4-year & 2-year \\
\hline $\mathrm{pH}$ & $7.3 \mathrm{a}^{*}$ & $7.2 \mathrm{a}$ & $7.1 \mathrm{~b}$ & $7.1 \mathrm{~b}$ \\
Total nitrogien $(\%)$ & $0.089 \mathrm{a}$ & $0.090 \mathrm{a}$ & $0.083 \mathrm{~b}$ & $0.083 \mathrm{~b}$ \\
Manganese $(\mathrm{ppm})$ & $23.6 \mathrm{a}$ & $24.3 \mathrm{ab}$ & $24.8 \mathrm{ab}$ & $27.0 \mathrm{a}$ \\
Potassium $(\mathrm{ppm})$ & $323 \mathrm{a}$ & $311 \mathrm{a}$ & $299 \mathrm{ab}$ & $279 \mathrm{~b}$ \\
Phosphorus $(\mathrm{ppm})$ & $19.3 \mathrm{a}$ & $17.2 \mathrm{a}$ & $14.3 \mathrm{~b}$ & $15.1 \mathrm{~b}$ \\
Organic matter $(\%)$ & $1.60 \mathrm{a}$ & $1.62 \mathrm{a}$ & $1.48 \mathrm{ab}$ & $1.39 \mathrm{~b}$ \\
\hline
\end{tabular}

"Indicates Duncan grouping. Means with the same letter are not significantly different among systems at the $\mathrm{P}=0.05$ level.

Table 5. Crop nitrogen tissue test levels, mid- to late season soil nitrate pools and yields of tomato and corn for 1990-1992 in different farming systems

\begin{tabular}{|c|c|c|c|c|c|c|}
\hline \multirow[b]{2}{*}{ System } & \multicolumn{3}{|c|}{ Tissue test level } & \multicolumn{3}{|c|}{ Crop yield } \\
\hline & 1990 & 1991 & 1992 & 1990 & 1991 & 1992 \\
\hline Tomato & \multicolumn{3}{|c|}{.... $\mathrm{NO}_{3}$ petiole $(\mathrm{ppm})$ early bloom .... } & \multicolumn{3}{|c|}{............ tons/acre ............. } \\
\hline Organic & $7,420 \mathrm{~b}^{*}$ & $1,530 \mathrm{~b}$ & $6,560 \mathrm{~b}$ & $30.7 \mathrm{c}$ & $28.2 \mathrm{c}$ & 42.7 \\
\hline Low-input & 12,490 a & $1,800 \mathrm{~b}$ & $12,230 \mathrm{a}$ & $36.3 \mathrm{~b}$ & $34.9 \mathrm{~b}$ & 42.9 \\
\hline Conventional 4-year & $12,730 \mathrm{a}$ & 4,280 a & 15,480 a & $36.8 \mathrm{ab}$ & $45.6 \mathrm{a}$ & 47.1 \\
\hline Conventional 2-year & 13,190 a & 4,800 a & 15,150 a & 40.0 a & $37.4 \mathrm{~b}$ & 41.3 \\
\hline Corn & \multicolumn{3}{|c|}{... \% nitrogen ear leaf at silking .... } & & & nst \\
\hline Organic & 2.97 & 2.4 & $2.4 \mathrm{~b}$ & 5.2 & $4.1 \mathrm{~b}$ & $4.9 \mathrm{~b}$ \\
\hline Low-input & 2.87 & 2.4 & $2.8 \mathrm{a}$ & 5.0 & $4.1 \mathrm{~b}$ & 5.9 a \\
\hline \multirow[t]{2}{*}{ Conventional 4-year } & 2.99 & 3.0 & $2.8 \mathrm{a}$ & 4.9 & $5.1 \mathrm{a}$ & $4.8 \mathrm{~b}$ \\
\hline & ns & ns & & ns & & \\
\hline
\end{tabular}

"Indicates Duncan grouping. Means with same letter are not significantly different among systems at $P=0.05$ level.

tns indicates that means are not significantly different.

TABLE 6. Nitrate concentrations in soil in corn and tomato plots during 1990-1992

\begin{tabular}{|c|c|c|c|c|}
\hline \multirow[b]{2}{*}{ Date } & \multicolumn{3}{|c|}{ Concentration (ppm) } & \multirow{2}{*}{ 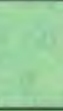 } \\
\hline & Organic & Low-input & $\begin{array}{c}\text { Conventional } \\
\text { 4-year }\end{array}$ & \\
\hline \multicolumn{5}{|l|}{$\begin{array}{l}\text { Tomato } \\
1990(0-30 \mathrm{~cm})\end{array}$} \\
\hline $3 / 25$ & $2.7 \mathrm{a}^{*}$ & $6.2 a b$ & $8.2 \mathrm{~b}$ & - \\
\hline $6 / 24$ & 12.9 & 19.7 & 12.4 & nst \\
\hline $8 / 6$ & 5.9 & 7.8 & 4.0 & ns \\
\hline $\begin{array}{l}1991(0-30 \mathrm{~cm}) \\
8 / 28\end{array}$ & \multicolumn{3}{|c|}{$1991(0-30 \mathrm{~cm})$} & ns \\
\hline \multicolumn{5}{|l|}{$1992(0-15 \mathrm{~cm})$} \\
\hline $3 / 31$ & 6.1 & 9.2 & 6.3 & ns \\
\hline $4 / 16$ & $5.6 \mathrm{a}$ & $4.9 \mathrm{a}$ & $3.3 \mathrm{~b}$ & - \\
\hline $7 / 2$ & 27.9 a & $23.1 \mathrm{ab}$ & $17.7 \mathrm{~b}$ & - \\
\hline $9 / 12$ & 23.4 & 24.1 & 17.9 & ns \\
\hline \multicolumn{5}{|l|}{ Corn } \\
\hline $3 / 25$ & $3.4 \mathrm{a}$ & $6.2 a b$ & $9.6 \mathrm{~b}$ & - \\
\hline $5 / 6$ & $34.3 \mathrm{a}$ & $38.2 \mathrm{a}$ & $14.3 \mathrm{~b}$ & - \\
\hline $6 / 24$ & 23.2 & 30.0 & 19.6 & ns \\
\hline $8 / 6$ & 20.2 & 17.5 & 25.8 & ns \\
\hline \multicolumn{5}{|l|}{$1991(0-30 \mathrm{~cm})$} \\
\hline $8 / 28$ & $10.6 \mathrm{~b}$ & $10.8 \mathrm{~b}$ & $23.3 \mathrm{a}$ & - \\
\hline \multicolumn{5}{|l|}{$1992(0-30 \mathrm{~cm})$} \\
\hline $4 / 17$ & $29.7 \mathrm{a}$ & $23.7 b$ & $17.3 \mathrm{c}$ & - \\
\hline $5 / 27$ & $34.3 \mathrm{a}$ & $32.2 \mathrm{a}$ & $10.0 \mathrm{~b}$ & - \\
\hline $10 / 27$ & 20.5 & 22.6 & 22.7 & ns \\
\hline
\end{tabular}



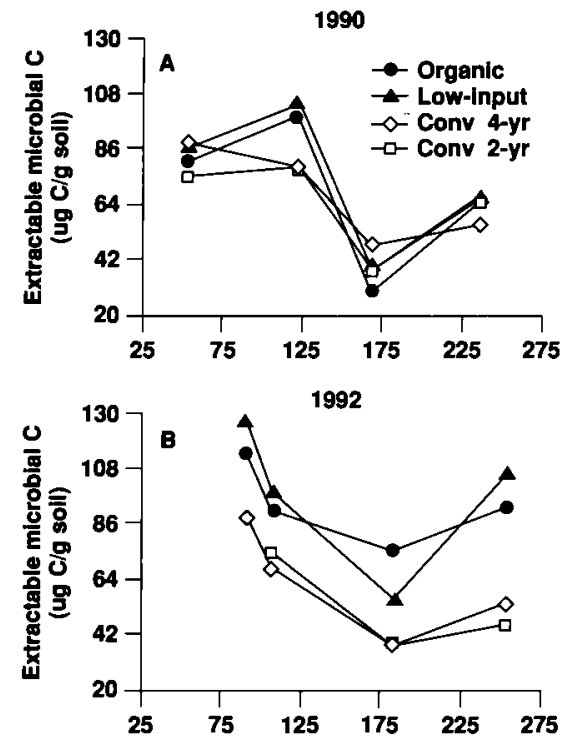

Fig. 3. Changes in microbial biomass carbon over the growing season in the four farming systems in 1990 and 1992.

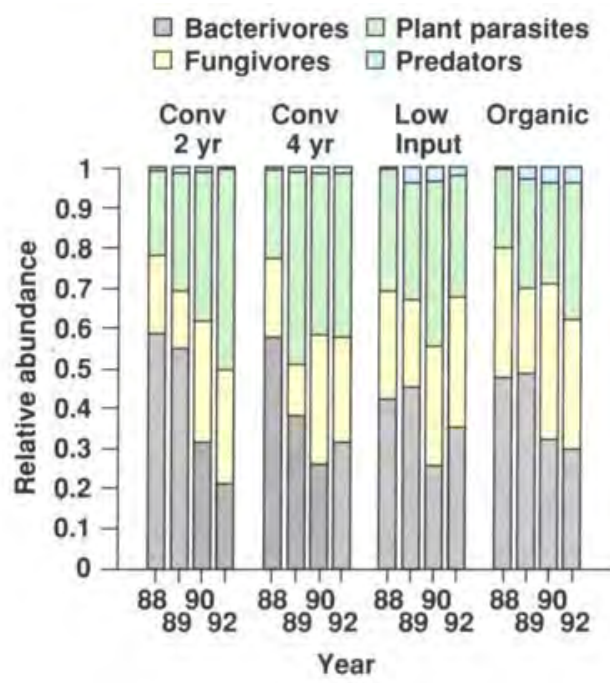

Fig. 4. Relative abundance of the different groups of nematodes in all crops in each of the four farming systems during 1988 to 1992.

method, which resulted in minimal incorporation of the cover crop. Reduced nitrogen availability to the organic and low-input corn plants in 1991 was evident from the lower percent nitrogen in the leaf and perhaps from the lower soil nitrate levels in late August relative to conventional plots (table 6). In 1992, low tissue nitrogen coincided with lower yields in organic versus low-input plots, but could not explain the lower yield of the conventional relative to the low-input plots (table 5).

Microbiology. Microbial biomass carbon (MBC) is an estimate of both the size of the total microbial community and the mass of potential plant nutrients contained within the cells of microorganisms. MBC was measured in tomato plots four times between March and September in both 1990 and 1992. Samples were also measured in December 1990 and May 1991. Levels of MBC fluctuated in all systems over the growing season, showing an increase in late March to May, a decline in the mid-growing season and an increase again by early fall (fig. 3). In 1990 (fig. 3A), the only significant differences $(P=0.05)$ among the four farming systems occurred following the early April incorporation of the cover crop, at which time the MBC was higher in the organic and low-input systems. There were no significant differences in $\mathrm{MBC}$ among the farming systems in December 1990 and on May 20, 1991 (data not shown). In 1992, however, MBC was higher in the organic and low-input than the conventional systems throughout the growing season (fig. 3B). The differences between the cover cropped systems and the conventional systems in 1992 were significant $(P=0.05)$ for all days except the April 17 sample. A mid-season crash in MBC was observed in all systems in 1992; however, MBC did not decline as much in the cover cropped systems as in the conventional systems.

For most sample dates, there were no significant differences (at $\mathrm{P}=0.05$ ) in $\mathrm{MBC}$ between the organic and low-input systems and no significant differences between the conventional 2 -year and conventional 4-year systems. Even though the low-input system received some of its nitrogen as inorganic fertilizer (see pp. 14-19), the similar dry matter inputs in the organic and low-input systems (table 3 ) may have contributed to similar levels of MBC.

The ratio of MBC to total soil organic carbon has been suggested to reflect the proportion of organic matter that is available as a source of plant nutrients. In European studies, MBC has been observed to constitute a lower percentage of the total organic carbon in monoculture plots than in plots that are cropped in rotations and/or amended with manure. In our study, the percentage of total organic carbon that is MBC in 1992 ranged from 1.4 to $5 \%$ in all farming systems. The highest percentages were measured in the low-input and organic systems.

Seasonal trends in $\mathrm{MBC}$ in our study differed from what has been observed in other more temperate climates of the United States where cropping system studies have been conducted. In our study, relatively high levels of microbial biomass appeared to be maintained over the winter, whereas the lowest levels measured occurred during mid- to late summer. Questions remain regarding how much of the fluctuation in MBC is due to temperature and moisture and whether management practices can be used to regulate microbial populations.

Nematodes. Prior to 1988, the field site of this experiment consisted of a number of separate and unrelated research plots of conventionally managed wheat, alfalfa and beans. There was considerable variability among the plots at the time of the initial 1988 nematode inventory; however, this variability has declined over time (data not shown). The proportion of nematodes of each feeding habit (that is, whether they feed on bacteria, fungi, plants or other nematodes) in the soils under all crops in each farming system are categorized for each year in figure 4.

In the two conventional farming systems, the total numbers of all nematodes in the soil to 30-centimeter depth did not change significantly be tween 1988 and 1992 (table 7); however, by 1992 the plant parasitic species represented an increasingly larger proportion of the conventional 2-year community in comparison to the other systems (table 8, fig. 4). For more details on the plant parasitic nematodes in the SAFS project, see pp. 27-33. Although plant parasitic nematodes were likely to be present below our sampling depth of 30 centimeters, our goal in this project was not to perform an exhaustive inventory but to compare numbers among similar crops grown under different farming sys- 
tems. In contrast to the conventional systems, between 1988 and 1992, there were significant decreases in the total number of nematodes in the low-input $(P<0.05)$ and organic systems $(P<0.10)$ (table 7). While that is interesting, it is of greater importance to examine changes in nematodes with different feeding habits through time.

Thirteen species of bacterial-feeding nematodes have been identified in the soils of the SAFS project. They include Acrobeloides sp., Acrobeloides bodenheimeri, A. buetschlii, A. tricornis, Bursilla labiata, Cephalobus persegnis, Chiloplacus sp., Cruznema tripartitum, Diploscapter sp., Panagrolaimus detritophagus, Plectus sp., Rhabditis cucumeris and Stegelleta $\mathrm{sp}$. We are interested in these nematodes due to their potential for mineralizing nitrogen as a result of feeding on bacteria. The proportion of all nematodes that are bacterial feeders declined over the 4 years in all but the low-input farming system (fig. 4). We find the decline in the organic plots somewhat surprising given the high levels of microbial biomass measured in these plots. However, the samples for nematode inventory were taken in September in 1988 and 1992, considerably later than the period when the microbial biomass appears to be greatest.

The different farming systems are also altering the depth distribution of biological activity in the soil, and our 30-centimeter deep cores provide samples that represent a wide range of soil conditions. More intensive sampling in 1992 and 1993 indicated different depth patterns in the conventional 4-year and organic farming systems (data not shown). In the top 15 centimeters of soil there were $50 \%$ more microbivorous nematodes in the organic soils than in the conventional 4-year system, whereas the proportions were reversed in the 15- to $30-$ centimeter layer. Differences in the distribution of nematode populations may reflect the higher concentrations of organic matter incorporated in the surface layer of soil in the organic compared to the conventional systems.

\section{We categorize} three species of nematodes in the soils of the SAFS project as fungal feeders, although two of these species (Aphelenchoides sp. and Ditylenchus sp.) may also feed on higher plants. The third fungal-feeding species is Aphelenchus avenae. The proportion of the nematode community represented by these nematodes had not changed over time in any of the farming systems by 1992 (fig. 4). In the conventional farming systems, however, the similar proportions actually represent greater numbers of fungal-feeding nematodes, since there are more nematodes in conventional than in organic and low-input systems (table 7). This may indicate differences in the nature and complexity of organic matter in the soils of the different systems. In the conventional systems, the organic matter incorporated into the soil is crop residue high in carbon content. The manure and leguminous cover crops incorporated into the low-input and organic plots have lower carbonto-nitrogen ratios than do the crop residues. It is possible that complex high carbon-to-nitrogen ratio organic materials may select for fungi rather

\begin{abstract}
Among the 13 species of bacterial-feeding nematodes identifled in the solls of the SAFS Project are Acrobeloldes bodenheimerl, top, and Cruznema tripartitum, bottom. Excess nitrogen generated by their grazing is released to the soil and becomes available for plant uptake.
\end{abstract}

than bacteria, and this may be reflected in the greater numbers of fungal-feeding nematodes in the conventional plots. It is possible that fungi, and thus their predators, may have been selected for in the conventional systems because of the ability of fungi to decompose relatively resistant organic material, e.g., high carbon-nitrogen ratio material. A higher proportion of fungi in the microbial

TABLE 7. Change in total number of nematodes in all crops, 1988-1992

\begin{tabular}{|c|c|c|c|c|}
\hline \multirow{2}{*}{$\begin{array}{l}\text { System } \\
\text { Conventional 2-year }\end{array}$} & \multirow{2}{*}{$\begin{array}{c}\text { No. in } 1988 \\
3,633\end{array}$} & \multirow{2}{*}{$\begin{array}{c}\text { No. in } 1992 \\
3,931\end{array}$} & \multicolumn{2}{|c|}{ P-value* } \\
\hline & & & ns & 0.63 \\
\hline Conventional 4 -year & 5,094 & 4,285 & ns & 0.54 \\
\hline Low-input & 5,585 & 2,828 & $*$ & 0.03 \\
\hline Organic & 3,673 & 2,735 & - & 0.08 \\
\hline
\end{tabular}




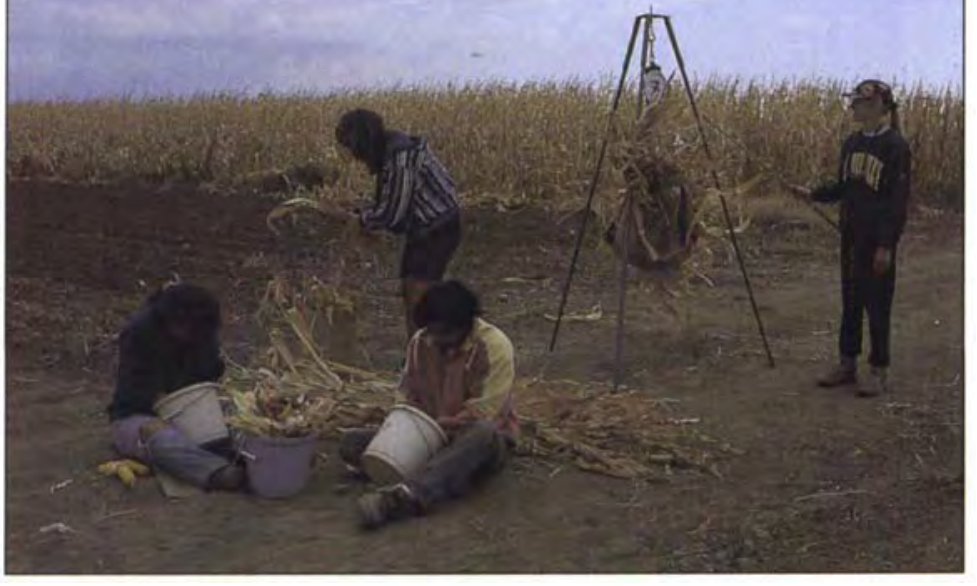

Corn residues were sampled for quantification of biomass and for tissue analysis.

community may result in organic matter that is lower in available nutrients; however, this hypothesis will require additional study.

Two species of nematodes in these soils represent groups whose feeding habits are not well defined but include predators on nematodes and other soil organisms. These predaceous nematodes were at rather low levels; however, in general they were more abundant, more consistently present and constituted a greater proportion of the total nematode community in the organic and low-input plots than in the conventional plots (fig. 4). The predatory species were identified as Prismatolaimus sp. and Eudorylaimus sp.

\section{Small but significant changes}

During the transition period, there have been small but significant changes in certain soil chemical properties in the organic and low-input systems. Although changes in organic matter are small, the average increase in the organic and low-input systems combined represents a $9 \%$ and $16 \%$ increase above that of the conventional 4- and 2-year systems, respectively. Nevertheless, total organic matter is a conservative measurement and does not reflect changes in the composition and potential fertility of the organic matter that also would have likely occurred with organic amendments.

As reported in other studies of the transition period, nitrogen deficiency appeared to be a problem in organic tomatoes. Relationships between crop yield and nutrient inputs, including crop growth response curves and assays of existing fertility, were originally derived from tests with inorganic fertilizers and may not be appropriate for organic forms of fertilizers. Nitrogen from organic sources is released in smaller increments and over a longer time than nitrogen from inorganic sources, which are applied in one or two large pulses. Fertilizer recommendations for organic sources will most likely need to consider the biological processes that govern nutrient availability. The results of our study and related work will be useful in identifying methods of assessing soil fertility in agricultural systems receiving organic inputs.

Distinct differences between the conventional and alternative management systems in the soil biological communities were evident by the 1992 growing season and were also observed in 1993 (data not shown). Many unanswered questions remain about the microbiological populations, such as why their biomass crashes midgrowing season and whether higher biomass levels are correlated to higher levels of activity and nutrient availability. Much more frequent measurements from the same soil samples are needed to elucidate the interrelationships among fertility and biological parameters and their contribution to the dynamic and complex patterns of nutrient cycling in agroecosystems. Similarly, questions remain regarding the microbivorous nematode community. Do their numbers indicate an important role in nitrogen mineralization due to grazing of fungi and bacteria, or do they merely reflect abundance of suitable food? Research is currently underway to address these questions.
Soil fertility can be problematic during the transition period from conventional to organic farming. A new organic farmer cannot use mineral fertilizers and many common pesticides and may thus be more vulnerable to crop loss than a conventional farmer. This is especially true in the transition period, when the soil biota may not be able to support the rates of cover crop decomposition needed to provide sufficient soil fertility in the early growing season. The low-input system provides an alternative, though lacking the economic incentives of an organic system, where some mineral fertilizer amendments and pesticides can be used as needed.

K.M. Scow is Assistant Professor, Department of Land, Air and Water Resources; O. Somasco was Project Manager, Department of Agronomy and Range Sciences; Nirmala Gunapala is a graduate student, Department of Land, Air and Water Resources; S. Lau is Research Assistant, Department of Nematology; $R$. Venette is a graduate student, Department of Nematology; H. Ferris is Professor, Department of Nematology; R. Miller is Extension Specialist, Department of Land, Air and Water Resources; and C. Shennan is Associate Professor, Department of Vegetable Crops, UC Davis. K. Klonsky and P. Livingston, Department of Agricultural Economics, also contributed to this article.

This research was supported by the $U C$ Sustainable Agriculture Research and Education Program (SAREP); the USDA Sustainable Agriculture Research and Education (SARE) program; the UC Division of Agriculture and Natural Resources (DANR); the CDFA Fertilizer Research and Education Program (FREP); the Fertilizer Inspection Advisory Board; and the USDA Cooperative State Research Service under Agreement no. 91-COOP-1-6590, jointly funded by the U.S. Environmental Protection Agency (EPA) for the conduct of the Agriculture in Concert with the Environment Program. In addition, this work was supported by the EPA (R819658) Center for Ecological Health Research. Although the information in this article has been funded in part by the EPA and the USDA, it may not reflect the views of the agencies, and no official endorsement should be inferred. 